\title{
GRIMINAL LAW: FEDERAL GRIMINAL CODE SECTION 1001 CONSTRUED TO CONTAIN TWO DISTINCT OFFENSES
}

SEction 1001 of the Criminal Code provides criminal sanctions against persons who deal fraudulently with government agencies. ${ }^{1}$ Although the origin of the statute dates from $1863,{ }^{2}$ only recently have Government attorneys made frequent use of its provisions. ${ }^{3}$ In United States $v$. Diogo, ${ }^{4}$ the Court of Appeals for the Second Circuit supplemented the increasing body of judicial interpretation of section 1001 by examining a new point of discussion and resolving it in a questionable manner.

The defendant ${ }^{5}$ was an alien who contracted a sham marriage

118 U.S.C. $\$ 1001$ (1958): "Whoever, in any matter within the jurisdiction of any department or agency of the United States knowingly and willfully falsifies, conceals or covers up by any trick, scheme, or device a material fact, or makes any false, fictitious or fraudulent statements or representations, or makes or uses any false writing or document knowing the same to contain any false, fictitious or fraudulent statement or entry, shall be fined not more than $\$ 10,000$ or imprisoned not more than five years, or both."

${ }^{2}$ The original form of the statute appeared in the Act of March 2, 1863, ch. 67, 12 Stat. 696. It was subsequently collected and revised in REv. STAT. $\$ 5438$ (1875), and later included in the Criminal Code of 1909, ch. 321, $\S 35,35$ Stat. 1095 . In 1948, that section, as amended and embodied in 18 U.S.C. $\$ 80$ (1940), was divided into two parts in the Act of June 25, 1948, ch. 645, $\S \S 287,1001,62$ Stat. 698, 749. The relevant current codification is 18 U.S.C. $\$ 1001$ (1958).

${ }^{3}$ During the last ten years, federal courts in New York alone have witnessed a wide variety of prosecutions based on $\S 1001$. Government agencies involved have included: Armed Services Medical Procurement Agency, United States v. Private Brands, Inc., 250 F.2d 554 (2d Cir. 1957), cert. denied, 355 U.S. 957 (1958); Civil Service Commission, United States v. Salazar, 293 F.2d 442 (2d Cir. 1961); Department of Commerce, United States v. Sorkin, 275 F.2d 330 (2d Cir.), cert. denied, 362 U.S. 989 (1960); Federal Deposit Insurance Corporation, United States v. Kaskel, 23 F.R.D. 152 (E.D.N.Y. 1959); Immigration and Naturalization Service, United States v. Lange, 128 F. Supp. 797 (S.D.N.Y. 1955); Internal Revenue Service, United States v. Curcio, 279 F.2d 681 (2d Cir.), cert. denied, 364 U.S. 824 (1960); Post Office Department, United States v. Baumgarten, 300 F.2d 807 (2d Cir.), cert. denied, 370 U.S. 917 (1962); Treasury Department, United States v. Miller, 246 F.2d 486 (2d Cir.), cert. denied, 355 U.S. 905 (1957); United States Army, United States v. Fabric Garment Co., 262 F.2d 631 (2d Gir. 1958), cert. denied, 359 U.S. 989 (1959); United States Assay Office, United States v. Sheba Bracelets, Inc., 248 F.2d 134 (2d Cir.), cert. denied, 355 U.S. 904 (1957); United States Coast Guard, United States v. McQuade, 119 F. Supp. 742 (E.D.N.Y. 1954); United States Navy, United States v. Greenburg, 268 F.2d 120 (2d Cir. 1959).

4320 F.2d 898 (2d Cir. 1963).

- The facts related here are those which a jury could have found with regard to the defendant Diogo. The facts of the cases against other defendants, Gonzales and Costa, are not included. 
with a citizen of the United States in order to obtain non-quota immigrant status. ${ }^{6}$ The parties were married in New Jersey pursuant to an agreement whereby the citizen would be paid a sum of money and there would be no sexual relations between them. Thereafter, Diogo represented his change in marital status to the Immigration and Naturalization Service and, consequently, was granted the non-quota status. Nine months after the marriage, never having lived together as husband and wife, the couple obtained a Mexican divorce. Under section 1001, ${ }^{7}$ the Immigration and Naturalization Service obtained a conviction of Diogo for wilfully making "false, fictitious and fraudulent statements and representations" with respect to his marital status. ${ }^{8}$

The Court of Appeals reversed on what it termed a "well established" interpretation of section 1001-that the section contains two distinct offenses, each of which requires different proof to sustain a conviction.9 The court reasoned that on the one hand, the offense of "concealment of a material fact" requires proof of wilful nondisclosure by means of a trick, scheme, or device. On the other hand, "false representation" requires proof of some type of actual falsity. Applying this interpretation to the situation presented in Diogo, the court construed the indictment for "false, fictitious or fraudulent statements or representations" to be in substance a charge of the offense of "false representations"10 requiring proof of actual falsity. Since the couple was married according to the law of New Jersey, the court found no actual falsity in Diogo's representations. ${ }^{11}$

${ }^{\circ}$ Immigration and Nationality Act $\S 101(\mathrm{a})(27)(\mathrm{A}), 66$ Stat. 169 (1952), 8 U.S.C. $\S$ 1101 (a) (27) (A) (1958). A non-quota immigrant may enter the United States without regard to the numerical limitation placed on persons of his national origin.

The defendants were convicted under three statutes: 18 U.S.C. $\$ 1001$ (1958), 18 U.S.C. $\S 1546$ (1958) (false statement in application for visa), and 18 U.S.C. $\$ 371$ (1958) (conspiracy to commit an offense or to defraud the United States). The Court of Appeals pointed out that the cornerstone of the charges was violation of $\S 1001$. and its decision treats that charge alone. $320 \mathrm{~F} .2 \mathrm{~d}$ at 902.

${ }^{8}$ See counts two, three and four of the indictment.

- 320 F.2d at 902.

${ }^{10}$ This construction of the indictment was apparently conceded during the argument on appeal. $320 \mathrm{~F} .2 \mathrm{~d}$ at 902 . In view of the costliness of this concession, one wonders if the prosecution contested this point sufficiently. It seems legitimately arguable that the indictment for "false, fictitious or fraudulent statements or representations" contained charges of both actual falsity and wilful nondisclosure. Actual falsity is self-evident in the words "false... statements," and wilful nondisclosure could be implied from the words "fraudulent... representations." See note 31 infra.

11320 F.2d at 905-07. In the court's view, since proof of actual falsity must be made when the indictment is for false representations, the jury must find both that the statements were literally false and that Diogo knew them to be false. The 
The court distinguished two almost identical cases on which the Government had relied most heavily ${ }^{12}$ and implied that although a conviction might have been obtained on an indictment for the offense of "concealment of a material fact,"13 the indictment did not charge that offense. This "variance" between the pleading and proof appears to be the primary basis of the reversal. ${ }^{14}$

The sufficiency of a pleading is tested by settled principles which require that an indictment fulfill two distinct purposes.15 First, the pleading must clearly depict the offense being charged so that the accused may impose a plea of former jeopardy in the face of a subsequent prosecution for the same offense. Secondly, the accused

court noted that the statement by Diogo that he was married could be interpreted as either true or false, i.e. that he was married according to the law of his domicile or that he was married with the intent of establishing a life together with his spouse as Congress undoubtedly intended in the Immigration and Nationality Act. Because of this ambiguity on the face of the representations, the necessary actual falsity depended solely on Diogo's intent at the time he made the statment. The court apparently felt that there was not enough evidence as to Diogo's intent at that time to justify the verdict below.

${ }^{12}$ Lutwak v. United States, 344 U.S. 604 (1953); United States v. Rubenstein, 151 F.2d 915 (2d Cir. 1945). In both cases the convictions were upheld, but the court pointed out that in each, concealment as well as false representation was charged. The court in Diogo concluded: "We do not read [Lutwak] to suggest that a prosecution for false representations can be grounded upon the omission of an explanation, which omission only carries with it implications of a state of facts which were not... true.' To so hold would be to distort the language of the statute and assimilate the separate offense of concealment into the different one of false representations solely because of a similarity of prohibited objectives." $320 \mathrm{~F} .2 \mathrm{~d}$ at 905 . (Emphasis in original.)

${ }^{13}$ By distinguishing Lutwak and Rubenstein on the ground that in both of them the offense of concealment of a material fact was charged, the court implied that if concealment had been charged in Diogo, the result would have been governed by Lutwak and Rubenstein. 320 F.2d at 905. Apparently, the court's theory would be that when the indictment is for concealment of a material fact, the jury is concerned with finding first that a material fact has not been disclosed, and secondly, that the defendant intended not to disclose it. Since there was no doubt in Diogo as to a material fact not being disclosed, the sole question would have been the "wilfulness" of the nondisclosure, and the court appeared willing to let the jury de. cide that question. The distinction between such a situation and the actual case appears to he in the fact that the first of the two required findings could have been made in a "concealment" situation, but in the actual case, there was not sufficient evidence to support the first required finding of actual falsity.

14320 F.2d at 902. Near the end of its opinion, the court suggested an additional reason for its decision when it rejected the Government's argument that the conviction should be affirmed on a theory of concealment if there is a failure to prove false representations. "Even assuming that the variance between pleading and proof did not prejudice appellants' interests, the...trial judge failed entircly to instruct the jury on ... [the concealment] theory of the case." Id. at 909.

The dissenting judge believed that even the failure of the trial judge to instruct the jury on the concealment theory did not result in prejudice to the appellants. In his view, both issues were clearly raised by the proof. Id. at 910 .

${ }^{15}$ E.g., Russell v. United States, 369 U.S. 749, 763-64 (1962), and cases cited therein. 
must be provided with sufficient particular information concerning the offense charged to enable him to prepare an adequate defense.

It seems that the court in Diogo was concerned about the sufficiency of the indictment with regard to the first of the two requirements: that it protect the accused from double jeopardy. ${ }^{16}$ This is indicated by the fact that all of the cases cited by the court as authority for the two-offense constrnction deal with the problem of jeopardy. ${ }^{17}$ Those cases indicate that the Diogo court correctly discerned the applicable principle for determining when two offenses exist for the purposes of double jeopardy. As set forth in Blockburger $v$. United States, 18 that principle states that "where the same act or transaction constitutes a violation of two distinct statuory provisions, the test to be applied in determining whether there is one or two offenses is whether each provision requires proof of an additional fact which the other does not."10

Several considerations indicate that even under the Blockburger test which the court adopts, the two-offense theory of section 1001 is tenuous. Upon examination of the terms "false representations" and "concealment," it seems that the only legitimate distinction

${ }^{10}$ As pointed out in note 14 supra, however, the court also indicated concern over the fact that some prejudice toward the defendants may have occurred even if the deficiencies in the indictment were overlooked. If this were the sole basis for the court's decision, no legal questions would be raised by the case since such prejudice is a matter of discretion for the trial judge. Kotteakos v. United States, 328 U.S. 750 (1946). However, this aspect of the case appears to be of secondary importance to the court.

${ }^{17}$ Both United States v. Uram, 148 F.2d 187 (2d Cir. 1945), and United States v. Kenny, 236 F.2d 128 (3d Cir.), cert. denied, 352 U.S. 894 (1956), involved questions of how many crimes were charged in the various counts of the indictments. In Uram, the defendant was claiming an unjustified double punishment; in Kenny, double jeopardy. However, United States v. Lange, 128 F. Supp. 797 (S.D.N.Y. 1955), does not deal with double jeopardy, but it offers only token support for a two-offense construction of the section. It is one of a rash of cases which consider it significant that the wording of the statute includes the words "material fact" only in connection with the "concealment" clause. The unfortunate conclusion often drawn from this observation is that materiality need not be proved if the indictment is in terms of the "false, fictitious or fraudulent statement or representation" clause. Such conclusions fail to appreciate the fact that the word "fraudulent" does appear in connection with the other clauses of $\S 1001$, and fraud necessarily involves materiality. See Twachtman v. Connelly, 106 F.2d 501, 506 (6th Cir. 1939). The majority of cases hold that materiality must always be an element of an offense under $\S 1001$. Gonzales v. United States, 286 F.2d 118, 120 n.2 (10th Cir. 1960).

18284 U.S. 299 (1932).

${ }^{10} \mathrm{Id}$. at 304. Both Uram and Kenny can be traced to the Blockburger principle. The Uram case cites Blockburger itself, while the Kenny case follows a more indirect route. Kenny cites Sealfon v. United States, 332 U.S. 575 (1948), which in turn relies on Pinkerton v. Unitéd States, 328 U.S. 640 (I946). Pinkerton cites Gavieres v. United States, 220 U.S. 338 (1911), which is rehed on in Blockburger. 284 U.S. at 304. 
which can be drawn between the two concepts is that a false representation requires an affirmative act while a concealment does not. A fact may be concealed without its being falsely represented. On the other hand, it is logically impossible to have a false representation without having a concealment at the same time because the true version of whatever facts are falsely represented must necessarily be concealed by the act itself. In fact, there seems to be no element of proof necessary to prove "concealment of a material fact" which is not also essential to prove "false representation"; so that, if the offense of false representation is proved, it seems that the offense of concealment of a material fact is proved by implication.20 Clearly, this does not meet the test laid down in Blockburger that each offense, not just one of them, contain some element not required in the other. By this analysis of the Blockburger rule, it would appear that whenever a defendant is prosecuted a second time under section 1001, he could successfully interpose a plea of former jeopardy. In other words, for purposes of double jeopardy, section 1001 contains but one offense. 21

Furthermore, congressional and judicial treatment of section 1001 and its forerunners further indicate that the statute is not to be narrowly construed as it must be under a two-offense theory. The 1948 revision of the Criminal Code ${ }^{22}$ severed what is now section 1001 from section 80 of the Criminal Code of 1940.23 Section 80 was a specific enumeration of various offenses which fell

${ }^{20}$ To paraphrase the court's words in Diogo, it would seem that proof of "actual falsity" would necessarily include a proof of "wilful nondisclosure by means of a trick, scheme or device." To hold otherwise, one would have to say that an outright falsehood does not constitute a trick, scheme or device. Such a narrow construction of those words seems hardly tenable.

${ }^{21}$ A similar test for identity of offenses is referred to as the "same evidence" test, whereby a second prosecution may be defeated by a plea of former jeopardy if the first indictment were such that a conviction could have been had upon proof of the facts contained in the second indictment. Burton v. United States, 202 U.S. 344, 380 (1906); Hall, Criminal LAw ANd Prockdure 902 (1949). See generally, id. at 902-06. A significant difference between the "same evidence" test and the Blockburger test may be seen in a situation where a defendant who has already been tried on a theory of false representations is prosecuted again on a concealment theory. As has been pointed out, a correct application of the Blockburger test would allow a plea of double jeopardy. On the other hand, application of the "same evidence" test would preclude a plea of double jeopardy, since (as the court in Diogo pointed out) proof of the elements of a concealment is not sufficient to convict on an indictment for false representations. This consideration suggests that perhaps the court in Diogo, although purporting to apply the Blockburger test, was in renlity applying the "same evidence" test.

${ }_{22}$ Act of June 25, 1948, ch. 645, 62 Stat. 683, 18 U.S.C. (1958).

${ }^{23}$ Act of April 4, 1988, ch. 69, § 35 (a), cl. 1-2, 52 Stat. 197. 
under a general heading of false claims against the Government. The second clause of section 80 became section 1001 under the heading: "Statements or entries generally." The wording of that clause consists of a logical breakdown in the possible means by which a fraud might be perpetrated. ${ }^{24}$ It is arguable that by enacting these words in a separate section of the revision, Congress intended to acknowledge the contrast between this broad language and the specific provisions in section $80 . .^{25}$ It seems that the intention was not so much to enumerate specific offenses as it was to define a single, broad offense. Judicial decisions have since, in fact, favored a broad construction of the statute. ${ }^{26}$ Rather than viewing the statute as an enumeration of various acts which constitute fraud upon the Government, the courts appear to recognize the congressional intent to protect the functions of the federal government from frustration and perversion ${ }^{27}$-in short, to protect the Government from fraud. A narrow and technical construction of the statute such as the two-offense theory in Diogo appears to thwart the intent of Congress and run counter to the majority of the cases.

Moreover, in the law of civil fraud, ${ }^{28}$ a concealment can be the "equivalent" of a false representation where there is a duty to speak, ${ }^{20}$ and a duty to speak can be raised where the concealer has

${ }^{24}$ See note 1 supra. The categories of $\$ 1001$ include: fraudulent representation, fraudulent concealment, and use of a fraudulent document.

25 The committee report gives no indication of congressional intent on this point. H. R. REP. No. 304, 80th Cong., 1st Sess. A80-81 (1948); S. REP. No. 1620, 80th Cong., 2d Sess. (1948).

so Ogden v. United States, 303 F.2d 724, 742 (9th Cir. 1962); Gonzales v. United States, 286 F.2d 118 (10th Cir. 1960), cert. denied, 365 U.S. 878 (1961); United States v. Leviton, 193 F.2d 848, 851 (2d Cir. 1951), cert. denied, 343 U.S. 946 (1952); United States v. Gottfried, 165 F.2d 360, 368 (2d Cir.), cert. denied, 333 U.S. 860 (1948); United States v. Stark, 131 F. Supp. 190, 205 (D. Md. 1955). Cf. United States v. Gilliland, 312 U.S. 86 (1941); Bramblett v. United States, 231 F.2d 489 (D.C. Cir.), cert. denied, 350 U.S. 1015 (1956); United Statés v. Goldsmith, 108 F.2d 917 (2d Cir.), cert. denied, 309 U.S. 678 (1940).

${ }_{27}$ United States v. Gilliland, supra note 26, at 92-93.

${ }^{28}$ Although this is a criminal statute and as such ought to be strictly construed, there is considerable authority that principles of civil fraud may apply to criminal fraud statutes. E.g., Mail fraud statute, 18 U.S.C. $\$ 338$ (1958): United States v. Buckner, 108 F.2d 921, 926 (2d Cir.), cert. denied, 309 U.S. 669 (1940); United States v. Brown, 79 F.2d 205, 211 (8th Cir. 1933). False claims statute, Rev. STAT. $\$ \S 3490$, 5438 (1875), 31 U.S.C. \$ 231 (1958): United States ex rel. Brensilber v. Bausch \& Lomb Optical Co., 131 F.2d 545, 546 (2d Cir. 1942), affirmed by an equally divided Court, 320 U.S. 711 (1943); United States v. United States Cartridge Co., 95 F. Supp. 384, 394 (E.D. Mo. 1950) (where the court notes the similarity of $\$ 1001$, at $394 \mathrm{n.8}$ ).

20 Restatement, TORTs $\$ 551$ (1938). E.g., Charles Hughes \& Co. v. SEC, I39 F.2d 434, 437 (2d Cir. 1943), cert. denied, 321 U.S. 786 (1944); Equitable Life Ins. Co. v. Halsey, Stuart \& Co., 112 F.2d 302 (7th Cir.), reversed on other grounds, 312 
undertaken to answer the inquiries of another..$^{30}$ Thus, in civil fraud, when Diogo undertook to answer the inquiry of the Immigration and Naturalization Service, he was bound to avoid a deceiving or misleading response. Wilful failure to do so would constitute civil fraud, and the theory of the case-whether "false representation" or "concealment of a material fact"-would be immaterial, since in this situation the two are equivalent. ${ }^{31}$

In the light of these considerations: the Blockburger test, congressional intent and treatment in the courts, and analogous principles of civil fraud, the unqualified two-offense construction of section 1001 seems unsatisfactory. There is no legal distinction between a false representation and a concealment, and any attempt to create such a distinction is apt to be misleading. The broad language of the Diogo opinion opens the way for needless confusion, technicality, and uncertainty in prosecutions under this statute. ${ }^{\mathbf{2}}$

The practical consequence of the Diogo decision is that hereafter the prosecuting attorney will probably phrase his indictment in terms of "concealment of a material fact" regardless of which "offense" he hopes to prove. ${ }^{33}$ Whether his own theory of the case is

U.S. 410 (1941); Miller v. National City Bank, 69 F. Supp. 187, 197 (S.D.N.Y. 1946); United States v. Zgrebec, 38 F. Supp. 127, 130 (E.D. Mich. 1941).

${ }^{30}$ E.g., Parker v. Title \& Trust Co., 233 F.2d 505, 510 (9th Cir. 1956); New York Life Ins. Co. v. Gay, 36 F.2d 634 (10th Cir. 1929), cert. denied, 284 U.S. 624 (1931); Knox v. Anderson, 159 F. Supp. 795, 806 (D. Hawaii 1958); 37 C.J.S. Fraud $\$ 16(c)$ (1943).

${ }^{31} \mathrm{~A}$ closely related principle of civil fraud holds that " $\mathrm{A}$ statement in a business transaction which, while stating the truth so far as it goes, the maker knows or believes to be materially misleading because of his failure to state qualifying matter is a fraudulent representation." REsTatement, TORTs $\$ 529$ (1938) as quoted in Equitable Life Ins. Co. v. Halsey, Stuart \& Co., 312 U.S. 410, 425.26 (1941); Strand v. Librascope, Inc., 197 F. Supp. 743 (E.D. Mich. 1961). It appears from this principle that in civil fraud a fraudulent representation need not be actually false on its face. The court apparently gives no attention to this analogous principle when it holds that an indictment for "false, fictitious or fraudulent statements or representations," requires proof of actual falsity. (Emphasis added.)

${ }^{32}$ Although the broad language of the case seems quite clear, a fairly appealing limiting argument could be based on the fact that the court does mention an additional ground for its decision. See note 14 supra. That this may have been the primary consideration bchind all the talk of two distinct offenses is to some degree attested by the fact that it is this point to which Judge Clark directs a part of his brief but vigorous dissent. 320 F.2d at 910 .

${ }^{33}$ The prosecutor may choose to include the language of both offenses in his indictment-regardless of the theory. Unfortunately, this practice will provide no better notice to the accused as to the particulars of his offense than would an indictment for defrauding the Government-which has been criticized as vague or indefinite. See Goldstein, Conspiracy to Defraud the United States, 68 YaLE L.J. 405, 414-36, $441-46$ (1959). 
"false representation" or "concealment of a material fact," by charging the latter, he avoids the burden of having to prove "actual falsity." If he charges "concealment of a material fact" and proves all the elements of that offense, the issue of actual falsity need never be reached. ${ }^{34}$

s4 Moreover, since the statute makes no distinction between false representations and concealment of a material fact with respect to seriousness or punishment, the prosecutor serves no purpose by bearing the added burden of proving actual falsity. 